\title{
CHEMICAL ENGINEERING STUDENTS
}

A SURVEY of students adruitted to chemical engineering dopartmonts at univorsities and tochnical colleges in 1963 has been carried out by the Institution of Chernical Engineers in conjunction with Research Services, Itd.*. It covors all 19 institutions in tho United Kingdom offering a full-time first-year degree course in chemical engineering, including students taking sandwich courses. Valid replios to tho questionnaire totallod 931 , and the 608 from chemical engineers represented an 89 per cent response. The survey indicated that while the differenco botweon these groups of students was not as great as that between science and engineering students generally, students seeking a degree in chemical and mechanical engineering arc of higher ability than ongineering students in general. Chemical engineers originating from grammar or public schools showed no difference in ability, and while other schools hold their own for the better students they provided a higher proportion of poorcr students. 'The proportion of chemical engineers and chemists from public schools is lower than that of engineers or scientists in general.

Chemical engineers at grammar or public schools decide on their course at a considerably later stage than other students, only 8 per cent deciding on chemical engineering before taking tho Ordinary Level examinations, compared with 31 per cent of chemists, while 44 por cent choose within the second or third year of their advanced work (22 per cent for chomists). (Yhemical engineers from other schools decide on their course even later. Motivation of careers is greater for students in technical colleges than for university students. More chemical engineers prefer to work in the field of design, construction, installation and plant maintenunce than in other fields, most chemists electing for research and development work. The distribution of the intended field of work of students is often in marked contrast to that of the chartered membership of the corresponding professional engineering institution. Chemical engineers are better informed about the type of work they will be doing after leaving college and about the salary-levels to bo oxpceted than are other students, and 60 per cent would like to go abroad after completion of

* The Institution of Chemical L"noineers. The Choice of Chemical L'ngineering at Dniversity or Technical College: a Survey of Students Admitted in 1908 study compared with 41 per cent of chemists, 'oxperionce' being the motive most frequently given, with 'better opportunities for financial reward' a close second.

Most chemical engineers learned of the oxistence of their course from their chemistry teacher (28 per cent), general litoraturo on careers ( 23 per cent) and college or university prospectuses (20 per cent). Relatives and friends were a source of information for 20 per cent of the chemical onginoors from public schools, 14 per cent of those from grammar schools and 30 per cent of those from other sehools. Almost half the chemists were given this information by their chemistry teacher. The Institution of Chemical Engineers was the socond most frequently used single source for detailed information on the courso, after collogo or university prospectuses, this information reaching 35 per cent of the public school boys, 29 per cont of grammar school boys and only 16 per cent of other school boys. The impact of the professional institution on mechanical engineors was only 6 per cent and on chemists only 2 per cent, but there was no indication that chemistry teachers or careers masters who do not teach chemistry wore unable to supply detailed information on chemical engineering. For about half of all the students, sources connected with the school were decisive, chemical engineers quoting the chernistry teacher ( 16 per cent), literature from the Institution of Chomical Engineers (13 per cent) and (for public school boys only) people in the profession (23 per cent) as the most frequent single sources. Chemistry teachors decisively influenced 27 per cent of the chemists compared with 16 per cent of the chemical engineers, but the difference is unlikely to be due to careers masters who tcach chemistry.

Of all the chemical engineers, 64 per cent seriously considered taking another course ( 1 in 3 considered taking chemistry and 1 in 7 a branch of engineering). Among the chemists 1 in 8 and among the mochanical ongincors 1 in 28 onsidered chemical engineering. Of the chemical onginoors who considorod taking chemistry, 30 per cent decided against it because it offered fowor prospocts for a career than chemical engineering. Less than 5 por cent of all chemical engineers could have been students who were refused admission to chomistry departments.

\section{THE ANIMAL VIRUS RESEARCH INSTITUTE, PIRBRIGHT}

\begin{abstract}
HE Animal Virus Research Institute is the new name for the Foot and Mouth Disease Research Institute at Pirbright, Surrey, and the report which has recently been published covers the years $1961 \ldots 63 *$. The Institute is still primarily concernod with the prevention and control of foot-and-mouth disease, and includes the World Reference Laboratory for this disonse, but it is now intended that activitios be extended to cover other virus disoases of animals as woll. For this reason and because much of the research carried out at the Institute is of relevance to viruses in general a change of name was indicatod.
\end{abstract}

The main theatres of operation for control of foot-andmouth disease during the period reviewed were in SouthWost Africa, whoro extensive vacoinution wus earried out to control a large outbrenk, and the Middlo Fast, where the

* The Animal Virus Reseuroh Institute, Pirbright. Report for the years 1901 1963. Pp. 34. (Pirbright: The Animal Virus Research Institute,
African strain of virus beeame widespread in 1962. Such operations have naturally led to great demands on the Institutc, particularly for live attenuated vaccine. The consequent problem of production has, however, been eased by a major development described in the report, namely the establishment of a co-operative project with the Welloome Foundation. Under the new arrangements the Foundation will be responsible for production of live vaccine in a new building on the perimeter of the Instituto.

This development has freed Institute staff and facilities for the pursuit of the proper function of researeh. Much effort has gone into methods for producing attenuated strains of virus suitable for immunization, and into studies on the safety of such strains when used in vaccines. The basic resenreh which is reported may ultimatcly shod light on these and other problems. For example, genetic recombination has been achieved for the first tirne and may load to dotailed gonotic analysis of foot-and-mouth disease virus. Viral replication is under investigation in 